\title{
COLLOID OSMOTIC PRESSURES OF SERUM PROTEINS IN NEPHROSIS AND CIRRHOSIS : RELATIONS TO ELEC- TROPHORETIC DISTRIBUTIONS AND AVERAGE MOLECULAR WEIGHTS
}

\author{
BY S. H. ARMSTRONG, JR.,1 R. M. KARK, J. A. SCHOENBERGER, J. SHATKIN, \\ AND R. SIGHTS \\ (From the Department of Medicine, University of Illinois College of Medicine, the Presby- \\ terian Hospital of Chicago, and the Hektoen Institute for Medical Research of \\ the Cook County Hospital of Chicago)
}

(Submitted for publication July 2, 1953; accepted October 28, 1953)

\section{INTRODUCTION}

The albumin component is, by reason of size and net charge and concentration, chiefly responsible for plasmas osmotic activity (1). ${ }^{2}$

The validity of Starling's hypothesis in the dynamics of water balance in conditions associated with hypoproteinemia has been the subject of considerable recent discussion. The basic experimental problems involved have been considered by some of us in other publications $(2,3)$ and by many other authors (4-11).

The present senior authors, at first separately and now in collaboration, have had the problem of the relation of edema to serum colloid osmotic pressure under experimental observation in a wide variety of clinical situations. We have constantly faced the question: Do we have to measure colloid osmotic pressures, or can we predict from total protein and protein distribution data (usually readily available on metabolic ward patients) with sufficient accuracy to suit our thinking? For although many recent workers have made direct measurements, a certain amount of think-

1 This study was initiated during tenure of a Welch Fellowship in Internal Medicine of the National Research Council. Gratitude is expressed to Professor George Scatchard (Department of Chemistry, Massachusetts Institute of Technology) and to Miss J. Weeks of his staff, and to Professor E. J. Cohn (Department of Physical Chemistry, Harvard Medical School) and to Mr. M. J. E. Budka and Miss M. Hasson of his staff, for facilities and help, and to Dr. Murray Franklin of Cook County Hospital for clinical collaboration.

We are indebted to the Otho S. A. Sprague Institute of Chicago for support. The study presently has received grants from the United States Public Health Service.

2 In this paper osmotic pressure refers exclusively to colloid osmotic pressure or oncotic pressure. ing has been based on colloid osmotic pressures so predicted.

That plasma albumin levels in hypoproteinemic states, whether done by the Howe method (12) or, as has been the case in our more recent studies, by the electrophoretic method (13), can be correlated with osmotic pressures with sufficient precision to elucidate the dynamics of water balance between plasma and interstitial fluid is by no means certain from the recent literature. For example, the conclusion of Keys, Taylor, Mickelsen, and Henschel (14) that the osmotic pressure falls within the normal range in experimentally produced nutritional edema, an opinion based in part on electrophoretic measurements, is at variance with the low osmotic pressures measured directly by Govaerts (15) in war nutritional edemas.

Of the many studies in the last fifteen years (e.g., [16-22]), two may be taken to illustrate representative and sound approaches to the problem in presenting empirical linear equations relating measured osmotic pressures to albumin levels determined by the Howe method over a wide range of values on individual human sera. That of Wells, Youmans, and Miller (21) yields an average variation calculated from observed values of $\pm 11.56 \mathrm{~mm}$. of water. (The average variation of duplicate osmotic pressure determinations was only $\pm 2.55 \mathrm{~mm}$. of water.) Again, the best linear fit from the data of Wies and Peters (22) shows an average deviation of \pm 27.6 between observed and calculated values. These authors conclude: "Unless practicable methods for the measurement of the colloid osmotic pressure of serum can be greatly improved in accuracy, estimations ... may be quite as reliable . . . as direct measurements." 
Now, in point of fact, the reproducibility of osmotic pressure measurements obtainable by the use of the Hepp osmometer (23) as modified by Brown, Gee, and others, under Scatchard's direction, in the laboratory of Physical Chemistry at the Massachusetts Institute of Technology (24) is as good as, if not better than, the reproducibility reported by Wells, Youmans, and Miller. Moreover, comparative freedom from systematic errors (when schedule of work permits satisfactorily long equilibration times) has been shown by successful use in the determination of average molecular weights of purified plasma fractions (25).

The question then arises as to whether the difficulty in achieving close correlation with osmotic pressures does not arise from the nature of albumin and globulin measurements on sera. Thus, whereas in our hands the conventional Howe method yields results quite reproducible in the moderate hypoalbuminemia encountered in Laennec's cirrhosis, and good correlation with electrophoretic results has been achieved (26), in the extreme hypoalbuminemias of the nephrotic state we have not been able to attain either this degree of reproducibility or as clear a correlation with the more reproducible electrophoretic measurements (12).

Scatchard, Batchelder, and Brown (27) have proposed a relation between osmotic pressure, total protein concentration, and uncorrected electrophoretic distributions of albumin and globulin, based on measurements on normal pooled human plasma.

We have been interested in whether the reproducibility of electrophoresis (given the arbitrary nature of its analysis) together with Scatchard's relation would yield predictability over a wide range of osmotic pressures and protein distributions associated with certain disease states. In the low pressure range we have studied ascitic fluids of Laennec's cirrhosis in addition to serial sera of three patients with the nephrotic syndrome undergoing spontaneous diuresis induced by measles (28). In the moderately depressed to normal pressure range, we have studied serial sera of seven patients with Laennec's cirrhosis, in addition to sera of normal controls and serial sera on one patient undergoing measles in the absence of nephrosis.
We have also been interested in whether the form of plot $\frac{\text { colloid osmotic pressure }}{\text { protein concentration }}$ vs. protein concentration ( $\mathrm{p} / \mathrm{c}$ vs. $\mathrm{c})$ might throw any light on the difficulties in correlating measured pressure, protein distributions, and clinical phenomena. We have carried out a number of dilution studies of this type on sera of patients with Laennec's cirrhosis, in the nephrotic phase of adult and childhood chronic glomerulonephritis, and of normal adults.

The electrophoretic distributions in the sera of normal and cirrhotic patients are uncorrected. We have simultaneously measured electrophoretic distributions and specific refractive increments in the sera of patients in the nephrotic state; the latter measurements were made because our previous studies on sera of patients in the nephrotic phase have shown that it is necessary to correct the electrophoretic data for the differences in refractive properties of the albumin and of the lipoproteins which comprise most of the remainder of the electrophoretic diagram. The theoretical basis of these

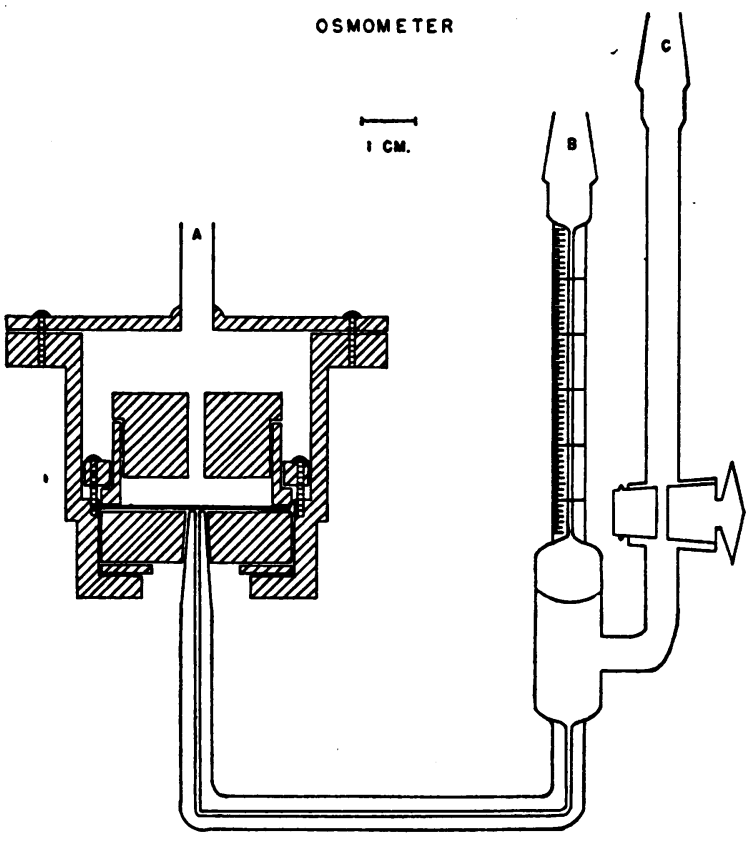

FIGURE 1

An operating description of this instrument, together with the basis for calculations outlined in Figure 2, has been made available in mimeographed form from the Department of Chemistry, Massachusetts Institute of Technology, Cambridge, Mass. (24). 
corrections has been presented in previous papers $(29,30)$.

\section{METHODS}

Serum samples, usually taken in the fasting state, were stored frozen at $-10^{\circ} \mathrm{C}$. until ready for analysis or studied at once. (Osmotic pressures of some individual sera, before and after freezing, were identical within the limits of the method.)

Osmotic pressures were measured directly in the modified Hepp osmometer in equilibrium with $.15 \mathrm{M}$ sodium chloride, in a thermostatically controlled bath at $25^{\circ} \mathrm{C}$. Membranes of appropriate permeability were prepared of nitrocellulose, according to the method of Pierce (31).

The most satisfactory membranes for our purposes have had a 4 to 1 ethylene glycol nitrocellulose ratio. Of any batch of membranes, a minority will allow enough albumin to leak to warrant discard; the remainder, if kept between uses in physiological saline, have been useful for periods up to six months. Incidence of serious protein leakage is diminished, but equilibration times are increased, with membranes of 3.5 or 3 to 1 ethylene glycol nitrocellulose ratios.

For 4 to 1 membranes, $8.3 \mathrm{Gm}$. anhydrous nitrocellulose (heat dried at $110^{\circ}$ and desiccator stored) is weighed quickly into a dry wide mouth ground glass stoppered bottle, and is thoroughly wetted with $32.2 \mathrm{Gm}$. anhydrous ethylene glycol. To this a mixture of $150 \mathrm{ml}$. absolute ethyl alcohol and $50 \mathrm{ml}$. anhydrous ether is added. The stoppered mixture is allowed to stand with periodic shaking until this no longer gives visible refractive index gradients. (A minimum of 24 hours is required.) Flat glass plates 3 inches square are floated on mercury in a closed box through which flows a stream of air which has previously passed through both a concentrated $\mathrm{H}_{2} \mathrm{SO}_{4}$ column and a $\mathrm{CaCl}_{2}$ column. After an hour of dry air passage, $5 \mathrm{ml}$. of the mixture is pipetted onto each plate and allowed to dry for 48 hours in the dry air current. The resultant membranes separate readily from the plates on dipping in physiological saline; they are thoroughly washed therein to remove all traces of ethylene glycol; cut by scissors to fit the osmometers, and tested for mechanical leaks by hydrostatic pressure; for excessive permeability by determination of protein content of underlying fluid after a 24-hour equilibration against a 10 per cent solution of normal human albumin in the osmometer.

Diagrams of the osmometer are given in Figures 1 and 2. While we often have used the dynamic method of measuring equilibrium (32) (vide Figure 2), recently we have preferred to take the additional time required for static equilibrium, particularly for $\mathrm{p} / \mathrm{c}$ vs. c plots, where maximum accuracy at low pressures is essential. Thus

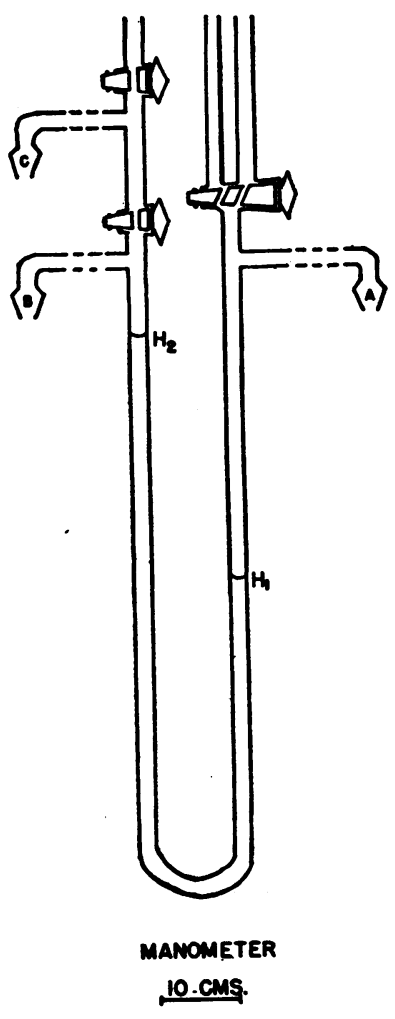

See Figure 1.
SAMPLE DYNAMIC OSMOTIC PRESSURE

CALCULATION

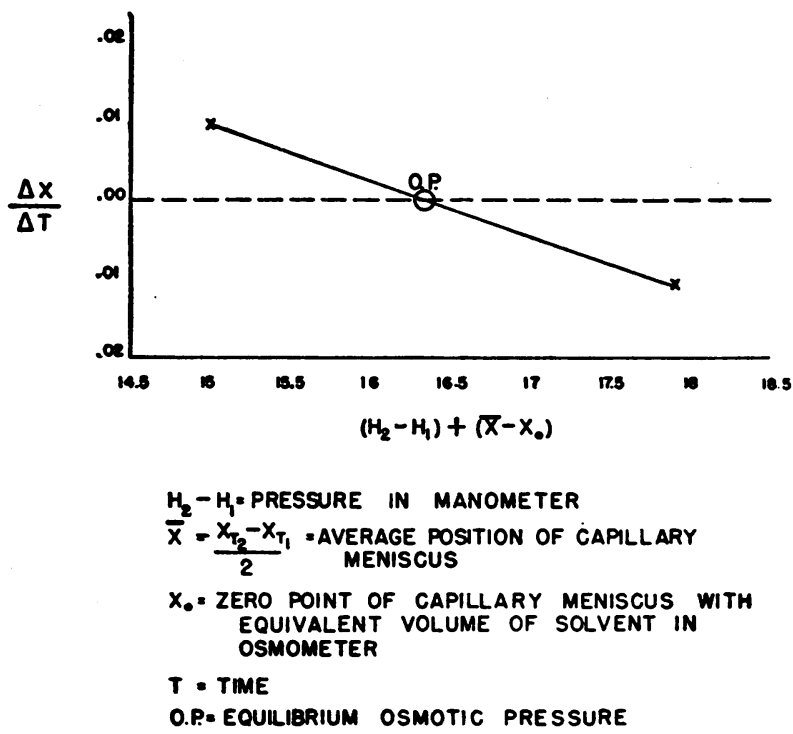

FIGURE 2 
NEPHROSIS

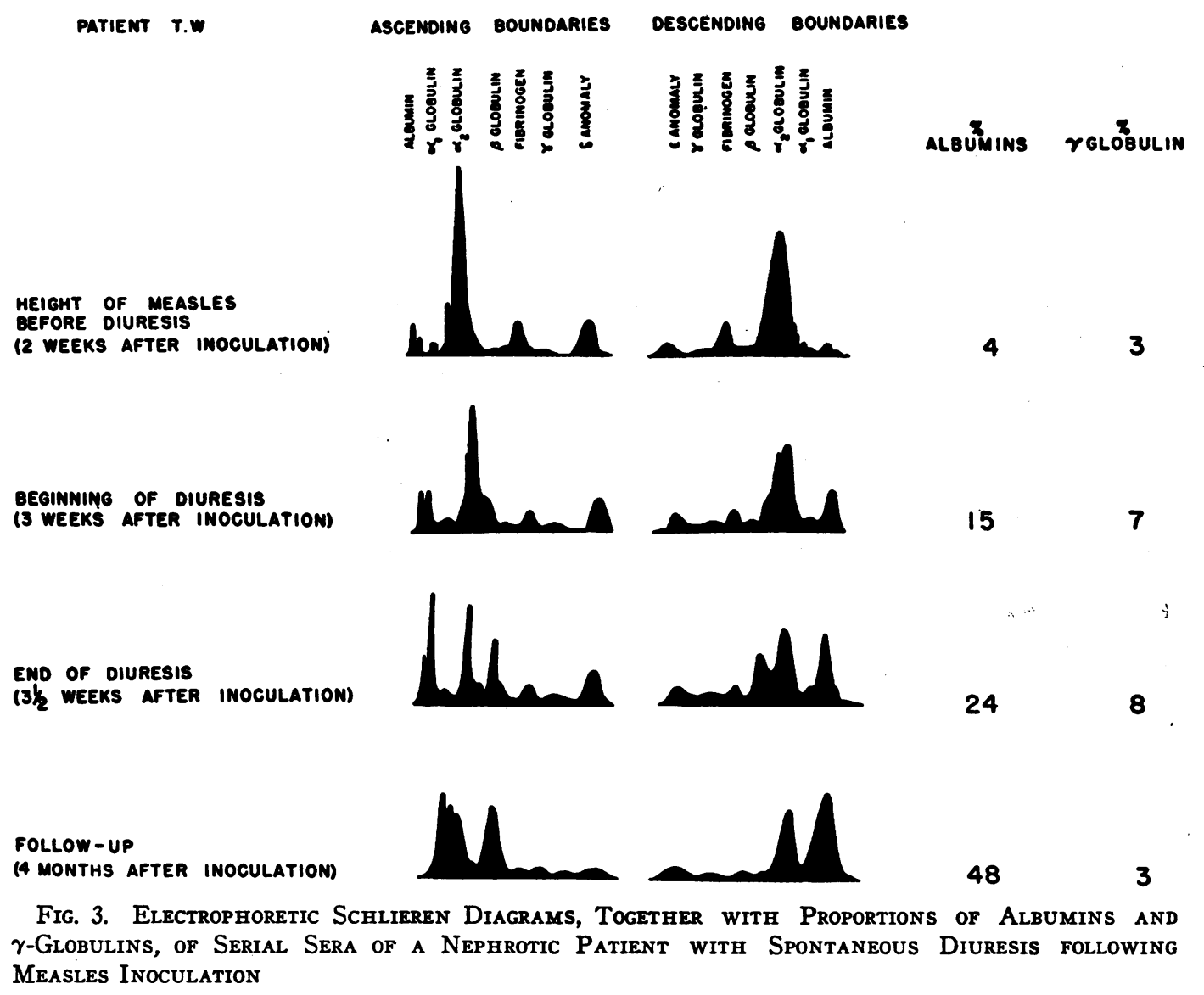

many of our pressure measurements have been checked over periods greater than four hours.

For p/c vs. $c$ plots sera 3 have been dialyzed for over 24 hours at $5^{\circ} \mathrm{C}$. against either 0.15 or 0.3 molal $\mathrm{NaCl}$, and osmotic pressures of serial dilutions, made with the dialysate, have been measured against it. (At 0.3 molal $\mathrm{NaCl}$, the Donnan effect is too small to be of significance in our work; at 0.15 molal $\mathrm{NaCl}$, it is larger though still negligible.)

For $\mathrm{p} / \mathrm{c}$ vs. $\mathrm{c}$ plots protein concentrations were measured by the dry weight technique previously described by one of us (30). Otherwise, nondialyzable protein nitrogen was determined by a modification of the method of Pregl (33). The weight of the total protein, exclusive of bound lipid, was estimated by using the conventional nitrogen factor of 6.25 .4

${ }^{8}$ Sera with visible lipemia from nephrotic patients were centrifuged at 18,000 r.p.m. in the cold, and the solutions underlying the surface fatty layer were taken for study.

4 The contribution of this protein to the refractive increment of the protein-lipid combination was estimated by use of a value of $1.17 \times 10^{-4}$ (in terms of grams of nitrogen
Electrophoretic analyses were carried out in sodium diethylbarbiturate buffer, $\mathrm{pH} 8.6$, ionic strength of 0.1 , in the Tiselius apparatus.

Where refractive indices were measured for correction of electrophoretic distributions, serum aliquots of approximately $8 \mathrm{cc}$. (whose volumes were known to within $.05 \mathrm{cc}$.) were placed in tight cellophane sacks and dialyzed against $0.3 \mathrm{M}$ sodium chloride. The contents of the sack per liter of solution). These values for nitrogen factor and specific refractive increment have been found in general to be characteristic of such proteins as albumin and $\boldsymbol{\gamma}$-globulin, whose lipid content in the natural state is small. The remainder of the refractive increment has been assumed to be due to protein-bound lipid, and the amount of the latter, in grams per $100 \mathrm{cc}$., can be estimated by use of a specific increment of $1.40 \times 10^{-3}$, in terms of grams per liter of solution, obtained by application of the LorentzLorenz equation (34), in form for binary mixtures, to the data of Dorinson, McCorkle, and Ralston (35). These estimates given in Table I, of course, ignore the possible contribution of bound carbohydrate to the refractive increment of the protein complex. 
were then removed, the sack thoroughly washed with the salt solution of composition identified with that against which dialysis was carried out, and the washings added to the contents. With the washings added, measurement of the final volume was carried out to within $.05 \mathrm{cc}$. Original serum concentrations were calculated by application of volume ratios to determinations on dialyzed protein.

Refractive indices of the sample and of the dialysate were measured and specific refractive increments $(\Delta N)$ $\Delta \mathrm{N}$ ( $\mathrm{Gm}$. prot. nitrogen/liter) $\times 10^{3}$ ) were calculated and applied to electrophoretic distributions as previously described (30).

\section{RESULTS}

The relation of serum colloid osmotic pressure to refractometrically corrected electrophoretic protein distribution during spontaneous remissions of severe nephrosis

In Figure 3 are presented the electrophoretic Schlieren diagrams of plasmas before, at the beginning of, at the end of, and four months after a typical measles induced diuresis of a nephrotic child. (These plasma diagrams show the fibrinogen component, which is missing from the sera reported in the tables.)

The initial patterns are characterized by very low albumins and gamma globulins, with corresponding elevations of the lipid-rich alpha and beta components. The progression of changes during diuresis closely follows the pattern observed by us (26) in spontaneous diuresis of the nephrotic stage of adult chronic glomerulonephritis, namely a progressive rise both in albumin and gamma globulin, with a diminution in the alpha-beta components and in fibrinogen (which contributes little, by reason of its high molecular weight, to the colloid osmotic pressure). The follow-up diagram four months after inoculation shows a further progression toward an albumin component normal in relative amount, but rather broad in distribution of mobilities, and a persistent reduction of gamma globulins.

In Table I are presented the detailed data on the sera of three patients clinically undergoing the same sequence of events.

A comparison of the uncorrected with the corrected albumin levels shows that the latter are considerably greater than the former.

The relation given by Scatchard and his co- workers is as follows :

$$
\frac{p}{c}=\frac{268(1-.68 \mathrm{~g})}{1-(.4+.9 \mathrm{pH}) \mathrm{c}}
$$

where $\mathrm{p}$ is osmotic pressure in $\mathrm{mm} . \mathrm{Hg}$

$$
\text { (or } \frac{\mathrm{mm} . \mathrm{H}_{2} \mathrm{O}}{13.6} \text { ), }
$$

c is total protein concentration in $\mathrm{Gm} . / \mathrm{cc}$.,

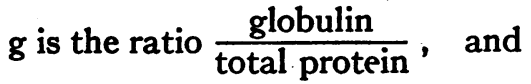

$\mathrm{pH}$ for determinations under routine conditions is taken as 7.4.

(This relation has been corrected by Scatchard [36] for a typographical error in the original publication [27].)

In Table II are given osmotic pressures as measured directly and as calculated by this equation.

The calculated values by no means fall with uniformity within $\pm 5 \mathrm{~mm} . \mathrm{H}_{2} \mathrm{O}$ of the experimental values (a range within which, with careful work, our experimental values are reproducible). At the end of diuresis associated with the nephrotic state, the calculated values are notably too low. If electrophoretic distributions uncorrected for refractive increments are used, deviations are even larger.

By simple algebraic transposition of Scatchard's relation, the expression $\frac{p}{c}\left(\frac{1-(.4+.9 p H) c}{268}\right)$ is linear in $\mathrm{g}$; the intercept being unity and the slope being the proportionality coefficient (taken from measurements on normal plasmas and albumin as - .68). This linearity implies the assumption of uniform average molecular weights and equivalent effects on pressure of protein-protein interaction for both albumins and globulins. In Figure 4 the values of this expression (based on the direct measurements of pressure in Table II) are plotted against $g$ (based on corrected electrophoretic distributions). Although the points show considerable scatter, for $\mathrm{g}>.8$ the available data are also consistent with a slope less, algebraically, than -0.68 ; moreover, most of the experimental points lie above the predicted line.

The relation of serum colloid osmotic pressure to uncorrected electrophoretic protein distribution of serum and ascitic fluid in hepatic cirrhosis

In Figure 5 are plotted (in fashion identical with Figure 4) experimental points for 27 sera 
TABLE I

Protein nitrogens, specific refractive increments, estimated protein-bound lipids, and electrophoretic albumin determinations: nephrosis + measles and measles control (sera)

\begin{tabular}{|c|c|c|c|c|c|c|c|c|c|}
\hline \multirow[b]{3}{*}{ Patient } & \multirow[b]{3}{*}{ Date } & \multirow{3}{*}{$\begin{array}{l}\begin{array}{c}\text { Protein } \\
\text { nitrogen } \\
\left(\frac{\mathrm{Gm} .}{100 c c .}\right)\end{array} \\
\text {. }\end{array}$} & \multirow{3}{*}{$\begin{array}{c}\text { Protein } \\
\left(\frac{\mathrm{Gm} .}{100 \mathrm{cc} .}\right)\end{array}$} & \multirow{3}{*}{$\underset{\times(10)^{3}}{\Delta\left(\frac{G m .}{\text { liter }}\right)}$} & \multirow{3}{*}{$\begin{array}{c}\text { Protein- } \\
\text { bound } \\
\text { lipid } \\
\left(\frac{\mathrm{cm} .}{100 c c .}\right)\end{array}$} & \multicolumn{4}{|c|}{ Electrophoretic albumin determinations } \\
\hline & & & & & & \multicolumn{2}{|c|}{ Uncorrected } & \multicolumn{2}{|c|}{$\begin{array}{l}\text { Corrected for } \\
\text { refractive } \\
\text { increments }\end{array}$} \\
\hline & & & & & & $\%$ & $\left(\frac{\mathrm{Gm} .}{100 \mathrm{cc} .}\right)$ & $\%$ & $\left(\frac{G m_{.}}{100 c c}\right)$ \\
\hline F. C. & $\begin{array}{l}\text { Before diuresis } \\
\text { During diuresis } \\
\text { End of diuresis }\end{array}$ & $\begin{array}{l}0.532 \\
0.564 \\
0.647\end{array}$ & $\begin{array}{l}3.33 \\
3.54 \\
4.04\end{array}$ & $\begin{array}{l}1.82 \\
1.79 \\
1.70\end{array}$ & $\begin{array}{l}2.4 \\
2.4 \\
2.4\end{array}$ & $\begin{array}{r}7 \\
10 \\
12\end{array}$ & $\begin{array}{l}0.23 \\
0.35 \\
0.48\end{array}$ & $\begin{array}{l}11 \\
15 \\
17\end{array}$ & $\begin{array}{l}0.36 \\
0.54 \\
0.70\end{array}$ \\
\hline A. G. & $\begin{array}{l}\text { Before diuresis } \\
\text { Before diuresis } \\
\text { During diuresis } \\
\text { During diuresis } \\
\text { End of diuresis }\end{array}$ & $\begin{array}{l}0.441 \\
0.514 \\
0.563 \\
0.821 \\
0.856\end{array}$ & $\begin{array}{l}2.76 \\
3.21 \\
3.52 \\
5.13 \\
5.35\end{array}$ & $\begin{array}{l}1.63 \\
1.83 \\
1.78 \\
1.73 \\
1.55\end{array}$ & $\begin{array}{l}1.4 \\
2.8 \\
2.4 \\
3.3 \\
2.3\end{array}$ & $\begin{array}{r}7 \\
8 \\
11 \\
15 \\
25\end{array}$ & $\begin{array}{l}0.19 \\
0.26 \\
0.39 \\
0.77 \\
1.34\end{array}$ & $\begin{array}{l}10 \\
13 \\
17 \\
22 \\
33\end{array}$ & $\begin{array}{l}0.27 \\
0.41 \\
0.58 \\
1.14 \\
1.77\end{array}$ \\
\hline W. L. & $\begin{array}{l}\text { Before diuresis } \\
\text { During diuresis } \\
\text { End of diuresis }\end{array}$ & $\begin{array}{l}0.521 \\
0.645 \\
0.858\end{array}$ & $\begin{array}{l}3.26 \\
4.07 \\
5.38\end{array}$ & $\begin{array}{l}1.65 \\
1.89 \\
1.57\end{array}$ & $\begin{array}{l}1.7 \\
3.3 \\
2.4\end{array}$ & $\begin{array}{r}6 \\
7 \\
18\end{array}$ & $\begin{array}{l}0.20 \\
0.29 \\
0.97\end{array}$ & $\begin{array}{r}8 \\
11 \\
24\end{array}$ & $\begin{array}{l}0.28 \\
0.46 \\
1.30\end{array}$ \\
\hline$\underset{\text { (control) }}{\text { J. C. }}$ & $\begin{array}{r}\text { Approximately } \\
\text { same periods } \\
\text { after measles }\end{array}$ & $\begin{array}{l}1.010 \\
1.090 \\
1.070 \\
1.080\end{array}$ & $\begin{array}{l}6.32 \\
6.82 \\
6.68 \\
6.76\end{array}$ & $\begin{array}{l}1.27 \\
1.26 \\
1.35 \\
1.30\end{array}$ & $\begin{array}{l}0.7 \\
0.7 \\
1.3 \\
1.0\end{array}$ & $\begin{array}{l}\mathbf{5 6} \\
\mathbf{5 3} \\
\mathbf{5 5} \\
\mathbf{5 4}\end{array}$ & $\begin{array}{l}3.54 \\
3.61 \\
3.68 \\
3.65\end{array}$ & $\begin{array}{l}61 \\
57 \\
63 \\
60\end{array}$ & $\begin{array}{l}3.85 \\
3.90 \\
4.25 \\
4.06\end{array}$ \\
\hline
\end{tabular}

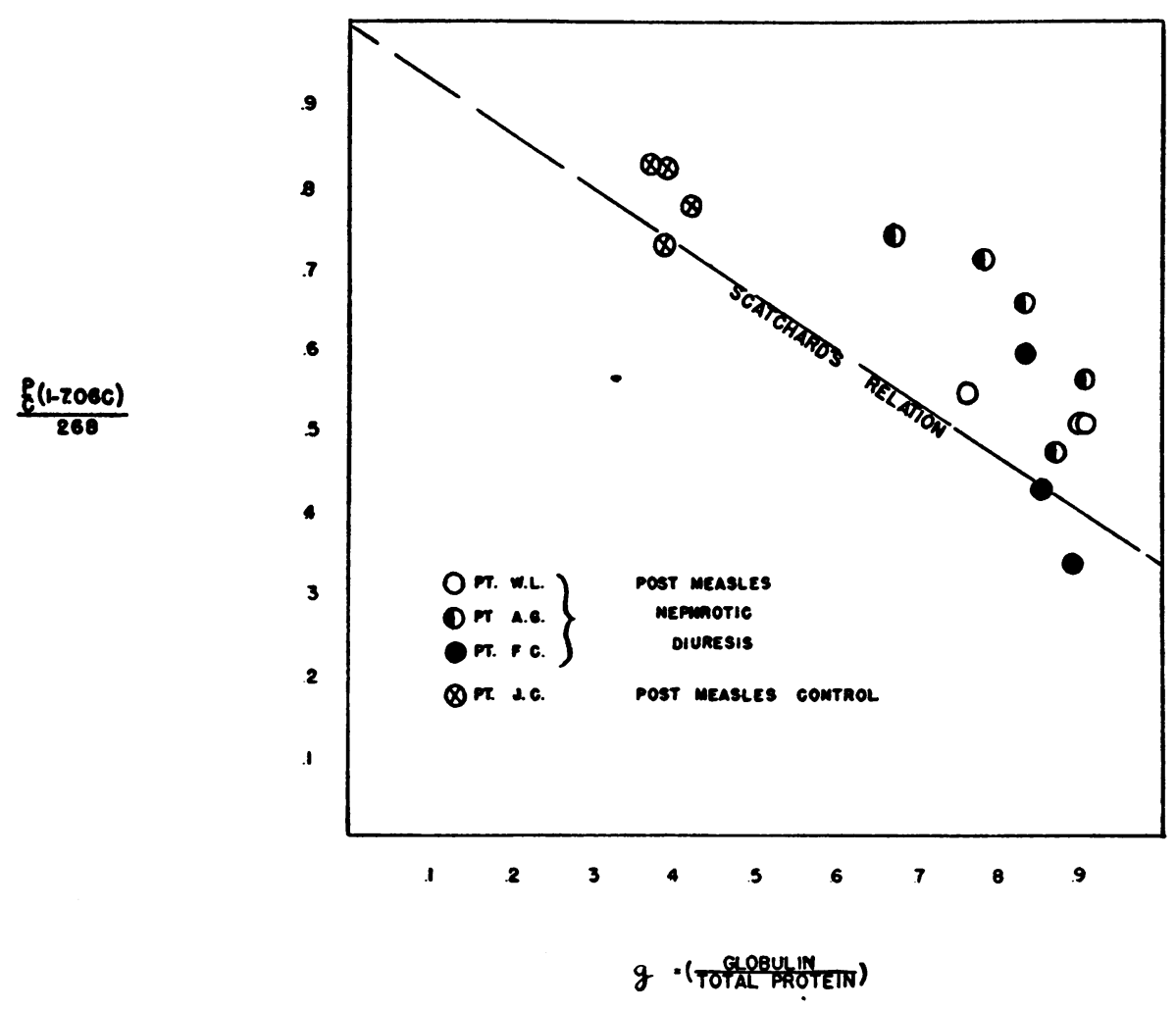

FIGURE 4

For description of this plot see the text. 
TABLE II

Osmotic pressures

\begin{tabular}{cccc}
\hline \hline & & \multicolumn{2}{c}{$\begin{array}{c}\text { Osmotic } \\
\left(\mathrm{mm} . \mathrm{H}_{3} \mathrm{O}\right)\end{array}$} \\
\cline { 3 - 4 } Patients & Date & Calculated & Measured \\
\hline F. C. & Before diuresis & 62 & 50 \\
$\begin{array}{c}\text { (nephrosis; } \\
\text { post-measles) }\end{array}$ & $\begin{array}{c}\text { During diuresis } \\
\text { End of diuresis }\end{array}$ & 72 & 74 \\
& & 90 & 118 \\
A. G. & Before diuresis & 50 & 71 \\
(nephrosis; & Before diuresis & 61 & 72 \\
post-measles) & During diuresis & 81 & 112 \\
& During diuresis & 138 & 208 \\
W. L. & End of diuresis & 172 & 230 \\
(nephrosis; & Before diuresis & 58 & 78 \\
post-measles) & During diuresis & 82 & 103 \\
End of diuresis & 153 & 172 \\
J. C. & & & \\
(normal & Approximately & 306 & 339 \\
post-measles & same periods & 342 & 371 \\
control) & after measles & 348 & 381 \\
& & 340 & 334 \\
\hline
\end{tabular}

and 19 ascitic fluids of patients with Laennec's cirrhosis together with 2 sera of normal adult patients. Although the latter lie close to the line of Scatchard's relation, both the sera and the ascitic fluids from cirrhotic patients show wide scatter above and below this. Thus, the relation seems inadequate for prediction of osmotic pressures in Laennec's cirrhosis.

In Figure 6 the osmotic pressures of the same sera of Figure 5 are plotted against the albumin concentrations of these sera in the fashion used by many to calculate regression equations by the method of least squares. The data show so much scatter that such a calculation seems of little value. The scatter is not improved by introducing more complicated functions of the concentrations of the various electrophoretic components (instead of the albumin concentration) as ordinate.

If, however, on Figure 6 a line is drawn from the origin through the two normal values furthermost on the extreme right, one is struck by the fact that the points for most osmotic pressures over $230 \mathrm{~mm}$. of water for sera of patients with Laennec's cirrhosis lie below this line, while for those pressures between 100 and 230 most of the points lie above the line. Indeed, if one eliminates from consideration all the ascitic fluid points, it would appear that in our cirrhotic patients the same range of albumin levels are found associated with quite low osmotic pressures as with pressures in the high range.

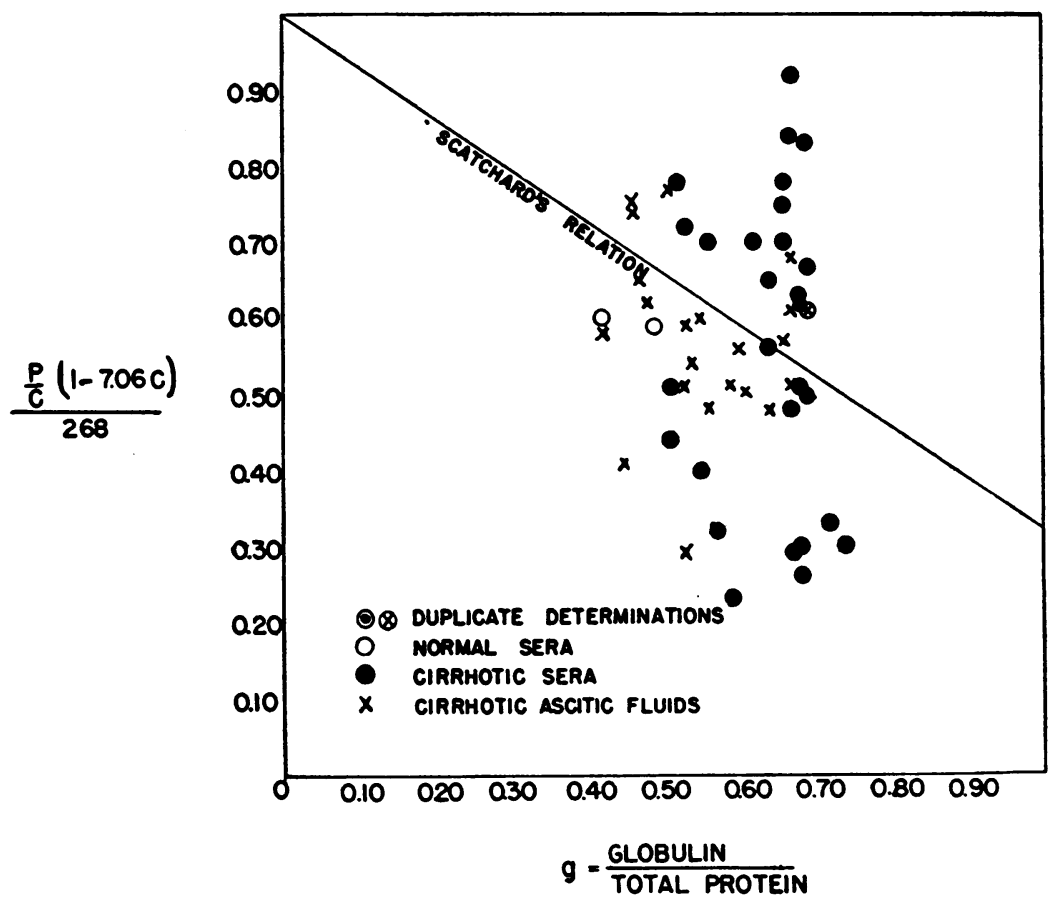

Figure 5

For description see text. 


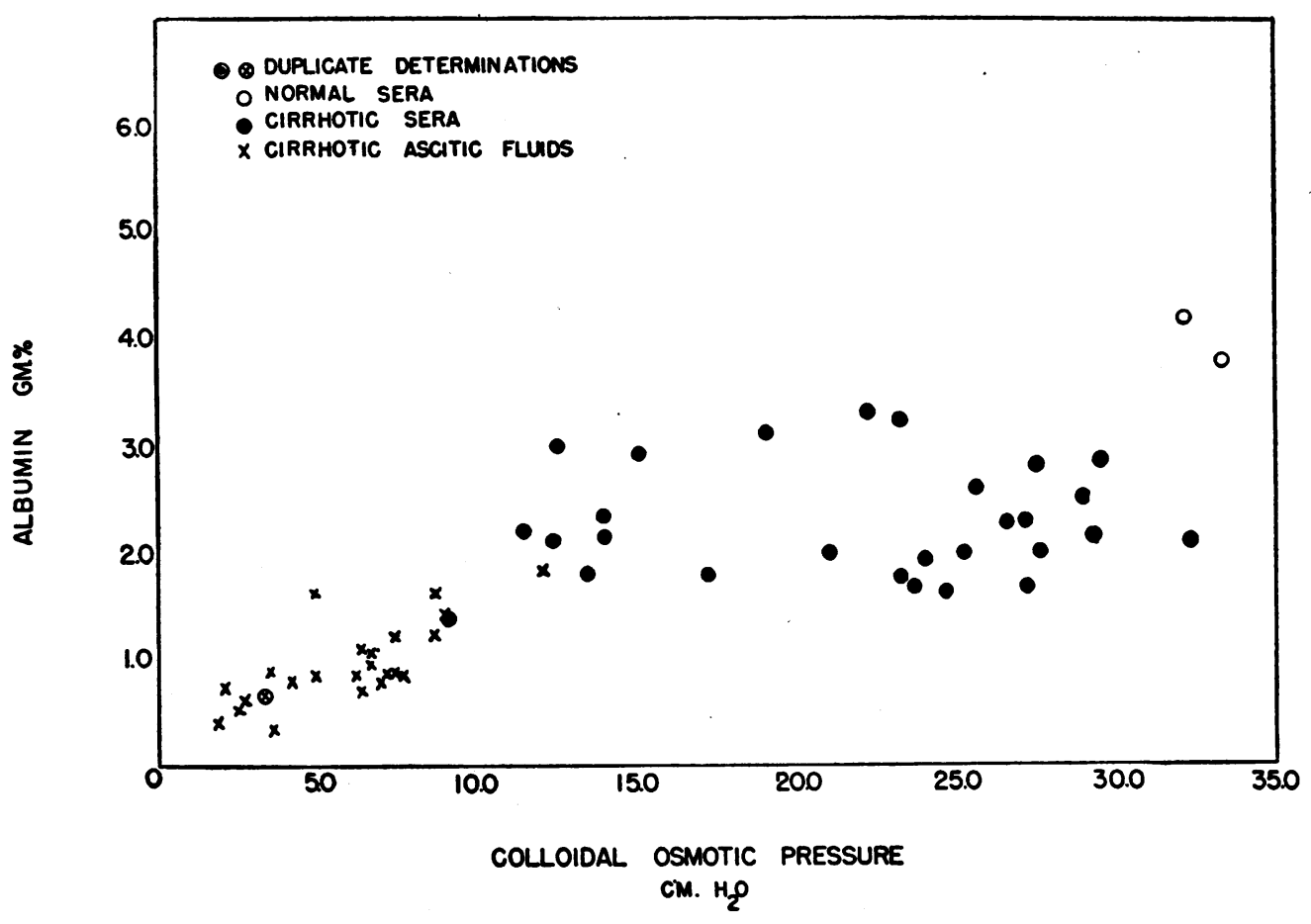

Figure 6

For description see text.

The problem thus posed is illustrated even more strikingly by the serial determinations of osmotic pressures, the serum albumin levels, and serum gamma globulin levels which are plotted against time for a single cirrhotic patient in Figure 7. This patient showed striking improvement on intensive dietary therapy over a period of half a year on our metabolic service. Toward the beginning of therapy (March-April) the serum osmotic pressures were consistently under $150 \mathrm{~mm}$. of $\mathrm{H}_{2} \mathrm{O}$ and the effective osmotic pressures (serum minus ascitic osmotic pressures) were in the neighborhood of $60 \mathrm{~mm}$. of water, a range as low as that found in the severe nephrotic syndrome. After clinical improvement, without any significant change in the electrophoretically determined levels of albumin or gamma globulin, both serum and effective osmotic pressures have almost doubled.

Among the questions raised by these findings is this: Are there proteins present in the serum of the patient severely ill with cirrhosis which, though indistinguishable by electrophoresis from the proteins of remission, have a very much smaller effect on colloidal osmotic pressure? If so, at least two possible bases come to mind. The first, a grossly altered net charge, seems unlikely on the basis of indistinguishable electrophoretic behavior. The second, a higher average molecular weight, might exist on the basis of either (a) a complexing of molecular species at the protein concentrations found in serum (with dissociation of the complex on the dilution ordinarily used in electrophoresis), or (b) the actual existence of a considerable proportion of proteins with molecular weights higher than those ordinarily associated with the known components in normal serum $(25,37)$.

\section{$\mathrm{p} / \mathrm{c}$ curves, average molecular weights, and the question of dissociable aggregates in the sera of nephrotic and cirrhotic patients}

Measurements of osmotic pressure of quantitative serial dilutions of sera are admirably adapted to the investigation of both the latter possibilities. The relation of osmotic pressure to concentration of serum proteins under physiological conditions can be represented by the following expression:

$$
\left(\frac{p}{c}\right)=A+B c
$$

where $p$ is osmotic pressure and $c$ is protein concentration (38). 


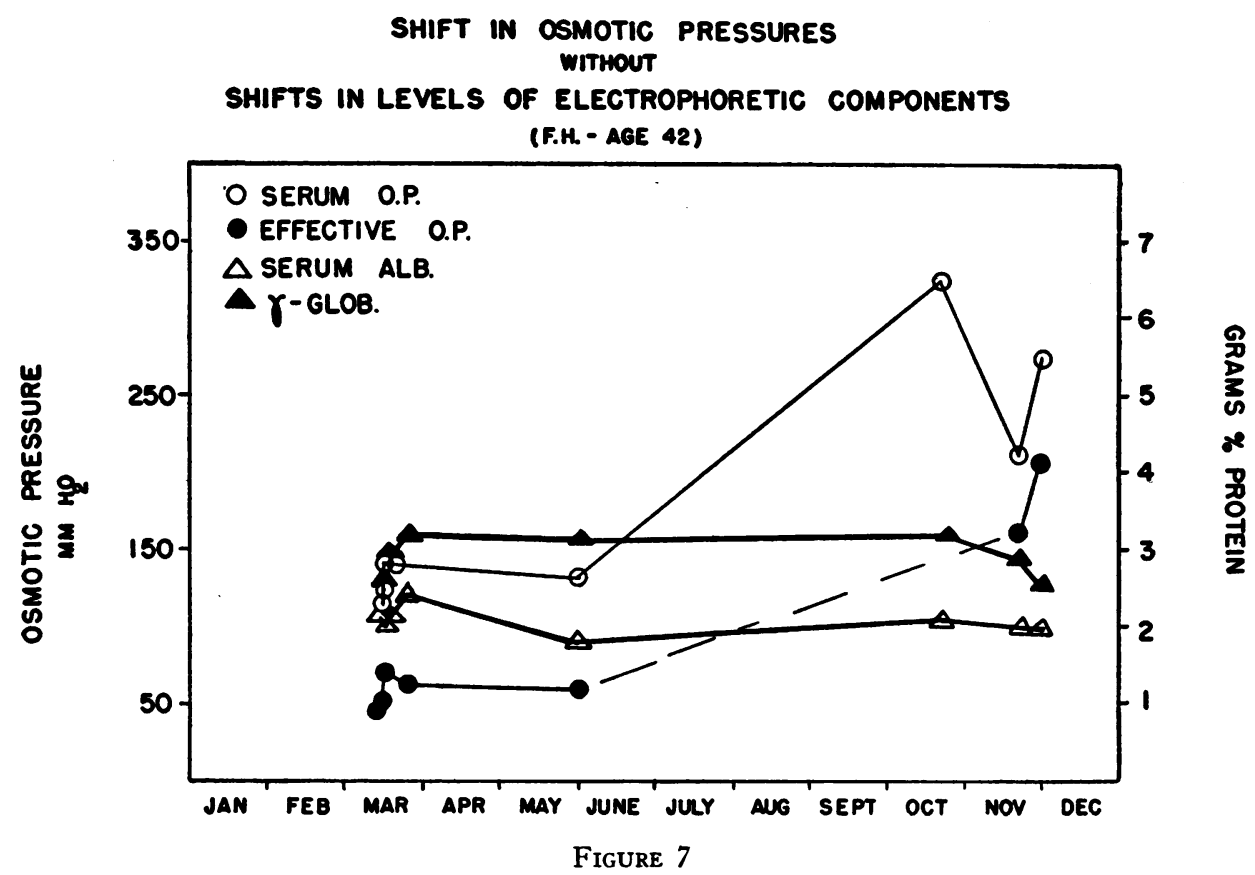

For description see text.

A (the intercept and a constant for a given mixture) is linear in the reciprocal of the average molecular weight at high dilutions; thus the extrapolation of a $\mathrm{p} / \mathrm{c}$ vs. $\mathrm{c}$ plot to infinite dilution gives a direct estimate of average molecular weights.

B (the slope) is as a rule independent of protein concentration in the range usually studied and is related to the interactions of the protein mole- cules with each other and with salts. For most protein fractions prepared from sera of normal subjects, the slope B plot has proved positive in sign, though variable in magnitude according to the proteins and the conditions of study (25).

The literature on $\mathrm{p} / \mathrm{c}$ plots of sera from patients with certain disease states is sparse. Wells, Youmans, and Miller (21) were well aware of the usual

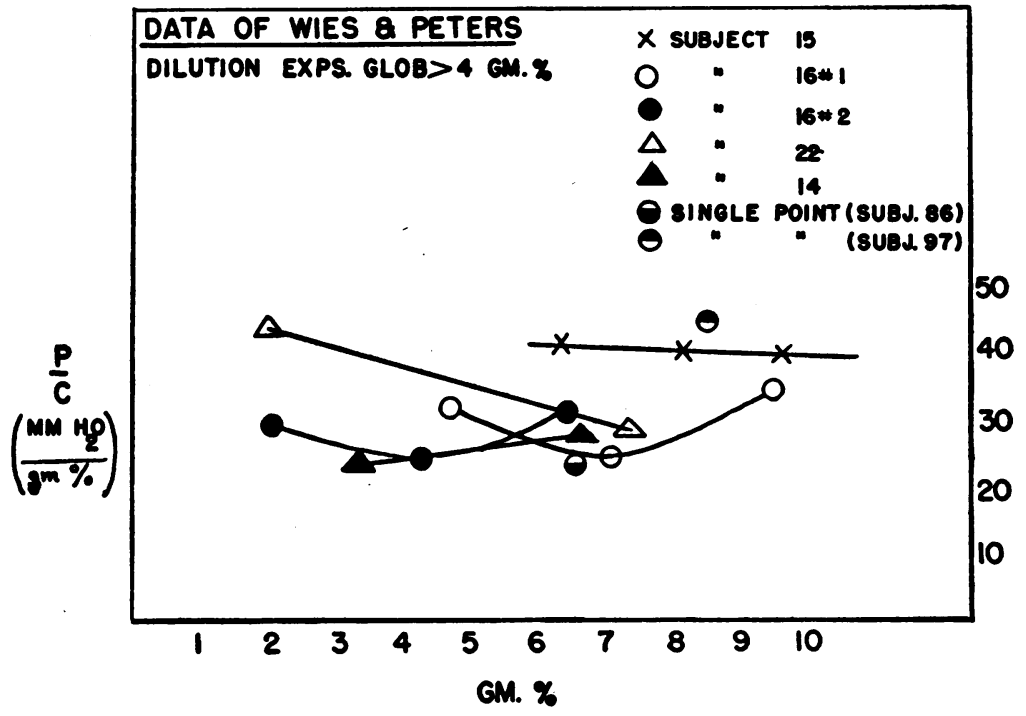

Frgure 8

For description see text. 


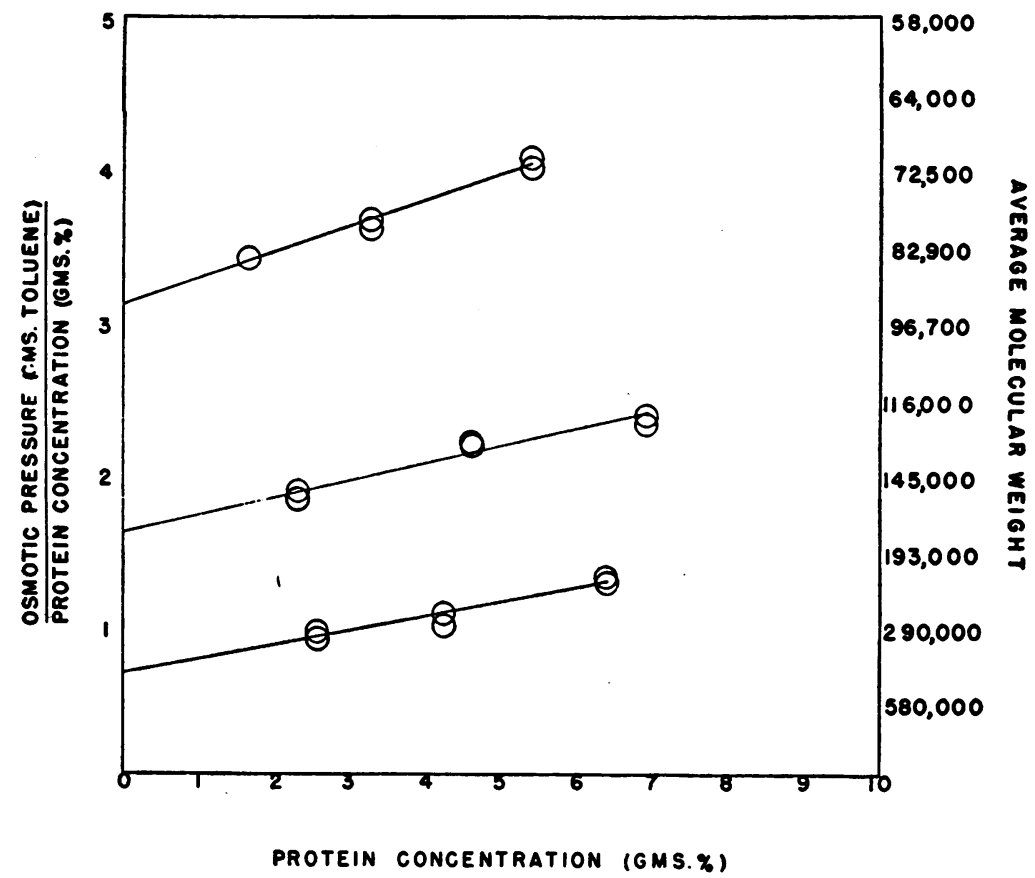

Figure 9

For description see text.

positive slope in their early publication. In Figure 8 are given the $p / c$ plots made from tabulated data of Wies and Peters (22) where globulin levels have been greater than $4 \mathrm{Gm}$. per cent. The curves drawn between their points suggest occasional negative slopes. This suggestion (subject to high demands of accuracy of measurement for this type of plot) is of unusual interest for this reason. A negative slope in the right-hand (concentrated) segments of the plots which either flatten or turn positive as concentrations approach zero, gives indication of the dissociation of a large molecule aggregate into component smaller units with increasing dilution.

We, therefore, renewed investigation of the intercepts and the slopes of $\mathrm{p} / \mathrm{c}$ vs. $\mathrm{c}$ plots in the following situations :

a) single serum specimens from five cirrhotic patients chosen for severity of edema and ascites;

b) single serum specimen from a cirrhotic patient chosen because of extreme hyper-gamma globulinemia despite absence of edema and ascites ;

\footnotetext{
8 We are indebted to Dr. Murray Franklin of the Cook County Hospital, Chicago, Illinois, for making these sera available for study.
}

c) twelve sera and three preparations of unfractionated urinary protein from eight patients in various stages of the nephrotic syndrome;

d) as controls we studied the proteins of sera of the normal male and of samplings from preparations of normal human serum albumin for pyrogen testing by the Commission on Plasma Fractionation.

In Figure 9 are plotted experimental points (in duplicate when available) for plasma from normal patients (top), for a patient with nephrosis in recent remission (middle), and for a patient with severe nephrosis (bottom). The average molecular weights corresponding to the intercepts on the left are given at right of the figure. The value for unfractionated normal plasma proteins $(95,000)$ is in good agreement with previous findings $(90,000)(27)$.

The proteins of the serum of the patient in the nephrotic phase of glomerulonephritis in moderate remission have an average molecular weight of about 160,000 ; the proteins of the patient in the severe nephrotic phase have an average molecular weight greater than 400,000 . The range (between 160,000 and 830,000 ) of the sera from the 
nephrotic patients is consistent with the known presence of large quantities of $\beta$-lipoproteins (of molecular weight greater than $1,000,000$ when separated from normal plasma [38]). That little of this high molecular weight protein gets into the urine is further confirmed by a maximum average molecular weight of 84,000 for the unfractionated urinary proteins recovered from our severest nephrotic patient. (Molecular weight of serum albumin from a normal patient is 69,000 [27] ; several samples of the product available for intravenous human use give an average molecular weight of 73,000 in our hands.)

For all sera of nephrotic patients and for the urinary proteins, the slopes (B) of all the $\mathrm{p} / \mathrm{c}$ plots (comparable to those of Figure 9 ) have been positive, though for sera showing high average molecular weights the magnitude of the slopes has been somewhat less than that seen in either sera of normal subjects or urinary proteins. ${ }^{6}$ This indicates that in sera of nephrotic patients, as for the $\beta$-lipoproteins separable from sera of normal patients, there is no dissociation of this type of macromolecule with dilution. ${ }^{7}$

6 This finding is consistent with the small positive slopes previously noted for crude preparations of normal $\beta$-lipoproteins.

I In this series of experiments we endeavored to compare immunochemically determined albumin levels with
The $\mathrm{p} / \mathrm{c}$ plot (together with the total protein level and electrophoretic distributions) for the cirrhotic patient with extreme hyper-gamma globulinemia is illustrated in Figure 10 and is representative of our results with the cirrhotic group. In this patient the average molecular weight (135,$000)$ is not very different from that $(140,000)$ expected for a mixture of eighteen parts of molecular weight 69,000 and 65 parts of 160,000 (this ignores the 17 parts contributed by the alpha and beta globulins in the electrophoretic diagrams). This value, however, is the largest average molecular weight encountered in six cirrhotic patients so studied. For the five water-logged cirrhotic patients, average molecular weights lay between this and the figure for the normal patients. Though values predicted from albumin and gamma globulin levels were consistently greater than those measured, average molecular weights were never sufficiently great to yield an explanation of findings for the patient illustrated in Figure 7 in terms of the presence of large quantities of macromolecules of

uncorrected electrophoretic albumin levels in order to get an estimate (using the normal molecular weights for the albumin and gamma globulin components) of the average molecular weights of the combined beta and alpha globulins. However, because we encountered sufficient diffculty with the optical measurement of end points in immunochemical titrations of these sera, we consider the comparison and subsequent calculations unreliable.

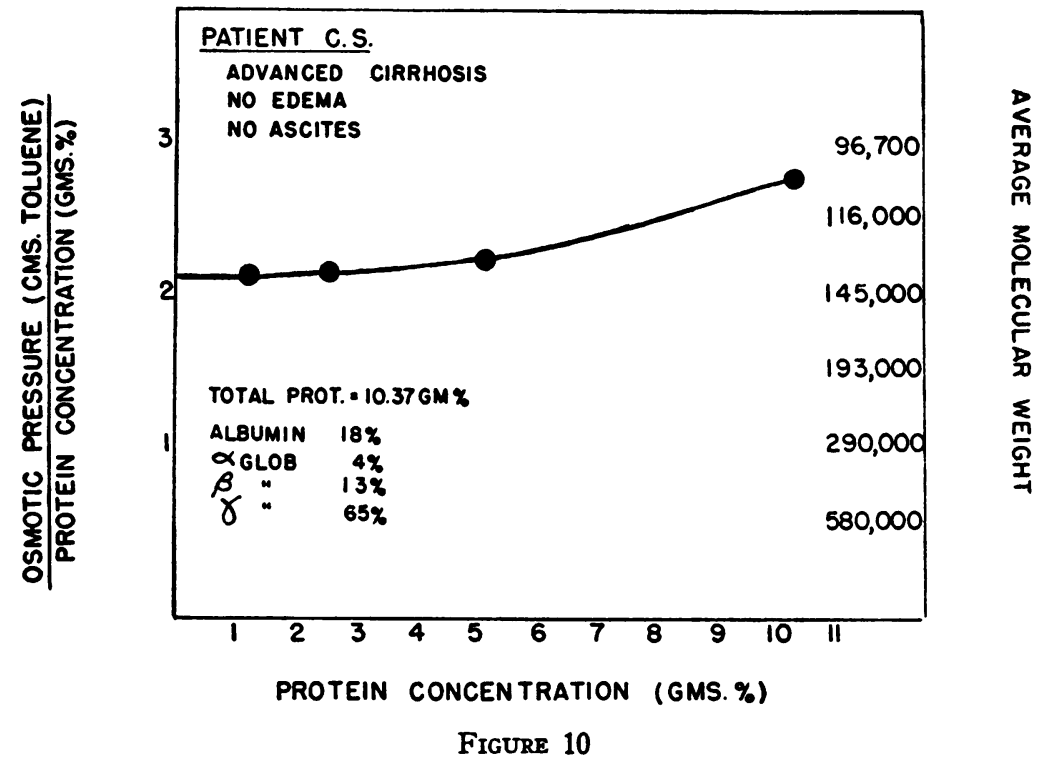

For description see text. 
size range comparable to those encountered in the nephrotic syndrome.

Likewise, the slopes of the $\mathrm{p} / \mathrm{c}$ plots of the cirrhotic group were consistently positive, thus yielding no explanation in terms of dissociation of macromolecules with dilution. Unfortunately, at the time this phase of our study was undertaken no early sera from the patient of Figure 7 remained.

\section{DISCUSSION}

The data here presented give clear indication that a comparatively recent empirical relation between osmotic pressure and electrophoretically determined albumin and globulin levels may not fit the data in the instance of the hypoproteinemia of various stages of the nephrotic syndrome as well as do older relations based on salting out determinations even though laborious refractometric corrections are carried out (39).

The situation for uncorrected electrophoretic data in Laennec's cirrhosis seems little better.

Taken in the light of the known heterogeneity, from the standpoint of size, shape, and net charge, of the proteins which in an electric field migrate in one component, these results are not surprising. Thus, for example, Oncley, Scatchard, and Brown (25) show that the alpha globulin component of serum from normal subjects contains a protein much closer in molecular weight to the normal serum albumins than to the normal gamma globulins. On the other hand, the lipid rich component of alpha-2-globulin has a molecular weight higher than the average molecular weight for serum gamma globulin.

If there is this much heterogeneity in the proteins of plasma from normal subjects, so, also, during the course of the clinical hypoproteinemias, there may well be shifts in the various molecular species of protein responsible for osmotic pressure $(40,41)$ without comparable shifts in either gross salting out or electrophoretic distributions. ${ }^{8}$

\footnotetext{
8 In studies on albumin metabolism in hypoproteinemic states, where albumin levels, rather than osmotic pressures, become of interest, the electrophoretic method as modified by corrections for refractive increments has a real advantage in reproducibility over solubility methods in the presence of very low albumin levels. Quite frequently, clinicians have sent to us sera of nephrotic patients with hypoproteinemia which have aroused interest by anomalously high albumin-globulin ratios in hospital
}

It is perhaps disappointing that the intercepts and slopes of the $\mathrm{p} / \mathrm{c}$ vs. $\mathrm{c}$ plots have not yielded the basis for the shifts of pressure without comparable electrophoretic shifts which we have seen clinically. We do plan to continue this exploration, particularly on serial sera of cirrhotic patients with very low osmotic pressures at the initiation of study. For it is possible that such sera will yield sufficient discrepancy between expected and measured average molecular weights; or between expected and measured slopes of the $\mathrm{p} / \mathrm{c}$ plot, to warrant fractionation procedures aimed at purifications of components responsible for unusual osmotic properties.

It is, however, our feeling on the basis of studies here reported that in experimental work aiming to relate forces governing either equilibrium, or a steady state of flow, of water across a capillary membrane, the wisest course in hypoproteinemic conditions is to measure the osmotic pressure directly until such time as there has been accumulated a detailed knowledge of the size and charge of the various proteins encountered in each clinical condition associated with hypoproteinemia. Direct measurements of osmotic pressure, on a set of osmometers simultaneously operated in a single thermostat bath, can be carried out without undue expense of time.

Thus we have not extended our own electrophoretic-refractive increment-osmotic pressure measurements to a larger series and tried to fit other empirical equations, for it has seemed to us $a$ priori unlikely that the same empirical equation can be used with sufficient accuracy on individual sera of varying hypoproteinemic etiologies. It takes a very small pressure gradient to move a great deal of water, given a big enough path; therefore, the accurate quantitation of small gradients is essential in the analysis of mechanism.

The significance of the time relations of these and other osmotic pressure measurements to movements of water in nephrotic, cardiac, cirrhotic, and other water-logged patients will be discussed in subsequent papers from this group.

\section{SUM MARY}

In the course of a series of direct osmotic pressure measurements on individual sera of nephrotic laboratories. These sera on electrophoresis have invariably shown the characteristic pattern of the nephrotic state. 
children undergoing spontaneous diuresis induced by measles, simultaneous determinations of protein nitrogen, electrophoretic distribution, and protein specific refractive increments have been carried out on a small group of sera, in order to see whether, with the most accurate possible use of the electrophoretic technique, a recently proposed relation for osmotic pressure of normal pooled plasma in terms of albumin and globulin levels can be applied. The results indicate that the relation gives a good correlation with measured pressures in the low pressure range, but in the intermediate range the predicted pressures are much lower than the measured and the discrepancies much larger than the reproducibility of the osmotic pressure method.

In a series of sera and ascitic fluids of cirrhotic patients studied by uncorrected electrophoresis, predictability of measured osmotic pressures proved not much better.

In serial sera from a patient with severe cirrhosis showing clinical improvement, osmotic pressure doubled without significant shifts in serum levels of electrophoretic components.

No evidence for either significant quantities of unusually large non-lipid bearing globulin molecules, nor of dissociation of larger complexes with dilution, could be obtained from intercepts or slopes of $\frac{\text { pressure }}{\text { concentration }} v s$. concentration plots in a small group of water-logged cirrhotic patients. Average molecular weights predicted from normal weights of electrophoretic albumins and gamma globulins, together with the distributions for certain disease states, proved only slightly higher than measured average molecular weights of the proteins of these sera.

Similar plots of sera from nephrotic patients gave evidence of high average molecular weights (range 160,000 to 830,000 ) varying with the stage of the syndrome. There was no evidence of dissociation of such aggregates with dilution.

These plots have not disclosed, but do not rule out, the existence of proteins of unusual osmotic properties as suggested by osmotic pressure measurements on certain patients with severe hypoproteinemia and edema.

It is concluded that in the extreme states of hypoproteinemia, where accurate balance between osmotic forces is needed for representation of the dynamics, direct measurements cannot be obviated.

\section{REFERENCES}

1. Cohn, E. J., Oncley, J. L., Strong, L. E., Hughes, W. L., Jr., and Armstrong, S. H., Jr., Chemical, clinical, and immunological studies on the products of human plasma fractionation. I. The characterization of the protein fractions of human plasma. J. Clin. Invest., 1944, 23, 417.

2. Armstrong, S. H., Jr., Mechanisms of action of serum albumin therapy in internal medicine. Am. J. Med., 1948, 4, 390.

3. Schoenberger, J. A., Kroll, G., Sakamoto, A., and Kark, R. M., Investigation of the permeability factor in ascites and edema using albumin tagged with $\mathrm{I}^{121}$. Gastroenterology, 1952, 22, 607.

4. Ralli, E. P., Robson, J. S., Clarke, D., and Hoagland, C. L., Factors influencing ascites in patients with cirrhosis of the liver. J. Clin. Invest., 1945, 24, 316.

5. Waterhouse, C., Bassett, S. H., and Holler, J. W. Metabolic studies on protein-depleted patients receiving a large part of their nitrogen intake from serum albumin administered intravenously. J. Clin. Invest., 1948, 28, 245.

6. Patek, A. J., Jr., Mankin, H., Colcher, H., Lowell, A., and Earle, D. P., Jr., The effects of intravenous injection of concentrated human serum albumin upon blood plasma, ascites and renal functions in three patients with cirrhosis of the liver. J. Clin. Invest., 1948, 27, 135.

7. Mankin, H., and Lowell, A., Osmotic factors influencing the formation of ascites in patients with cirrhosis of the liver. J. Clin. Invest., 1948, 27, 145.

8. Faloon, W. W., Eckhardt, R. D., Murphy, T. L., Cooper, A. M., and Davidson, C. S., An evaluation of human serum albumin in the treatment of cirrhosis of the liver. J. Clin. Invest., 1949, 28, 583.

9. Faloon, W. W., Eckhardt, R. D., Cooper, A. M., and Davidson, C. S., The effect of human serum albumin, mercurial diuretics, and a low sodium diet on sodium excretion in patients with cirrhosis of the liver. J. Clin. Invest., 1949, 28, 595.

10. Luetscher, J. A., Jr., Hall, A. D., and Kremer, V. L., Treatment of nephrosis with concentrated human serum albumin. I. Effects on the proteins of body fluids. J. Clin. Invest., 1949, 28, 700.

11. Gounelle, H. of the Robert Gould Research Foundation, Inc., in Symposia on Nutrition, Vol. II. Plasma Proteins, J. B. Youmans, ed., Springfield, I1l., Charles C Thomas, 1950, p. 195.

12. Thorn, G. W., Armstrong, S. H., Jr., Davenport, V. D., Woodruff, L. M., and Tyler, F. H., Chemical, clinical, and immunological studies on the products of human plasma fractionation. XXX. The use of salt-poor concentrated human serum albumin solution in the treatment of chronic Bright's disease. J. Clin. Invest., 1945, 24, 802.

13. Luetscher, J. A., Jr., Biological and medical applications of electrophoresis. Physiol. Rev., 1947, 27, 621. 
14. Keys, A., Taylor, H. L., Mickelsen, O., and Henschel, A., Famine edema and the mechanism of its formation. Science, 1946, 103, 669.

15. Govaerts, P., Pathogénie de l'œdème de famine in Enseignements de la Guerre 1939-45 dans la domaine de la Nutrition, Liege (Belgium), Maison Desoer, 1947, p. 23.

16. Peters, J. P., and Eisenman, A. J., The serum proteins in diseases not primarily affecting the cardiovascular system or kidneys. Am. J. M. Sc., 1933, 186, 808.

17. Myers, W. K., and Keefer, C. S., Relation of plasma proteins to ascites and edema in cirrhosis of the liver. Arch. Int. Med., 1935, 55, 349.

18. Butt, H. R., Snell, A. M., and Keys, A., Plasma protein in hepatic disease. A study of the colloid osmotic pressure of blood serum and of ascitic fluid in various diseases of the liver. Arch. Int. Med., 1939, 63, 143.

19. Post, J., and Patek, A. J., Jr., Serum proteins in cirrhosis of the liver. I. Relation to prognosis and to formation of ascites. Arch. Int. Med., 1942, $69,67$.

20. Butt, H. R., and Keys, A., Colloid osmotic pressure: Studies of normal individuals and of those with hypoproteinemia. Proc. Staff. Meet., Mayo Clin., 1937, 12, 566.

21. Wells, H. S., Youmans, J. B., and Miller, D. G., Jr., A formula and nomogram for the estimation of the osmotic pressure of colloids from the albumin and total protein concentrations of human blood sera. J. Clin. Invest., 1933, 12, 1103.

22. Wies, C. H., and Peters, J. P., The osmotic pressure of proteins in whole serum. J. Clin. Invest., 1937, 16, 93.

23. Hepp, O., Ein neues Onkometer zur Bestimmung des kolloid-osmotischen Druckes mit gesteigerter Messgenauigkeit und vereinfachter Handhabung. Ztschr. f. d. ges. exper. Med., 1936, 99, 709.

24. Scatchard, G., Brown, A., Bridgforth, R. M., Weeks, J., and Gee, A., A precision modification of the Hepp type osmometer. Department of Chemistry, Massachusetts Institute of Technology, Cambridge, Massachusetts, 1950 (mimeographed form).

25. Oncley, J. L., Scatchard, G., and Brown, A., Physicalchemical characteristics of certain of the proteins of normal human plasma. J. Phys. and Colloid Chem., 1947, 51, 184.

26. Thorn, G. W., Armstrong, S. H., Jr., and Davenport, V. D., Chemical, clinical, and immunological studies on the products of human plasma fractionation. XXXI. The use of salt-poor concentrated human serum albumin solution in the treatment of hepatic cirrhosis. J. Clin. Invest., 1946, 25, 304.

27. Scatchard, G., Batchelder, A. C., and Brown, A., Chemical, clinical, and immunological studies on the products of human plasma fractionation. VI. The osmotic pressure of plasma and of serum albumin. J. Clin. Invest., 1944, 23, 458.
28. Janeway, C. A., Moll, G. H., Armstrong, S. H., Jr., Wallace, W. M., Hallman, N., and Barness, L. A., Diuresis in children with nephrosis. Comparison of response to injection of normal human serum albumin and to infection, particularly measles. Tr. A. Am. Physicians, 1948, 61, 108.

29. Armstrong, S. H., Jr., Budka, M. J. E., and Morrison, K. C., Preparation and properties of serum and plasma proteins. XI. Quantitative interpretation of electrophoretic schlieren diagrams of normal human plasma proteins. J. Am. Chem. Soc., 1947, 69, 416.

30. Armstrong, S. H., Jr., Budka, M. J. E., Morrison, K. C., and Hasson, M., Preparation and properties of serum and plasma proteins. XII. The refractive properties of the proteins of human plasma and certain purified fractions. J. Am. Chem. Soc., 1947, 69, 1747.

31. Pierce, H. F., Nitrocellulose membranes of graded permeability. J. Biol. Chem., 1927, 75, 795.

32. Wagner, R. H., Determination of osmotic pressure, in Weissberger, A., Technique of Organic Chemistry. Vol. I-Part I, Physical Methods of Organic Chemistry, ed. 2, New York, Interscience Publishers, Inc., 1949, chapter XI, p. 487.

33. Pregl, F., Quantitative Organic Microanalysis, 2nd Eng. ed., Philadelphia, Blakiston Co., 1930.

34. Putzeys, M. P., and Brosteaux, J., L'indice de réfraction des protéides. Bull. Soc. chim. biol., 1936, 18, 1681.

35. Dorinson, A., McCorkle, M. R., and Ralston, A. W., Refractive indices and densities of normal saturated fatty acids in the liquid state. J. Am. Chem. Soc., 1942, 64, 2739.

36. Scatchard, G., The colloid osmotic pressure of serum. Science, 1951, 113, 201.

37. Scatchard, G., Batchelder, A. C., and Brown, A., Preparation and properties of serum and plasma proteins. VI. Osmotic equilibria in solutions of serum albumin and sodium chloride. J. Am. Chem. Soc., 1946, 68, 2320.

38. Oncley, J. L., Gurd, F. R. N., and Melin, M., Preparation and properties of serum and plasma proteins. XXV. Composition and properties of human serum $\beta$-lipoprotein. J. Am. Chem. Soc., 1950, 72, 458.

39. Armstrong, S. H., Jr., Budka, M. J. E., Hasson, M., and Weeks, J., The relation of serum colloid osmotic pressure to refractometrically corrected electrophoretic protein distribution during spontaneous remissions of severe nephrosis in Studies in Medicine. Springfield, Ill., Charles C Thomas, 1951, Chapter 3, p. 17.

40. Barr, D. P., Russ, E. M., and Eder, H. A., Protein-lipid relationships in human plasma. II. In atherosclerosis and related conditions. Am. J. Med., 1951, 11, 480.

41. Russ, E. M., Eder, H. A., and Barr, D. P., Proteinlipid relationships in human plasma. I. In normal individuals. Am. J. Med., 1951, 11, 468. 